Maurer School of Law: Indiana University

Digital Repository @ Maurer Law

1980

\title{
The Differential Sentencing of White-Collar Offenders in Ten Federal District Courts
}

Ilene Nagel Bernstein

Indiana University School of Law

John Hagan

University of Wisconsin - Madison

Celesta Albonetti

Indiana University - Bloomington

Follow this and additional works at: https://www.repository.law.indiana.edu/facpub

Part of the Criminal Law Commons, and the Criminology and Criminal Justice Commons

\section{Recommended Citation}

Bernstein, Ilene Nagel; Hagan, John; and Albonetti, Celesta, "The Differential Sentencing of White-Collar Offenders in Ten Federal District Courts" (1980). Articles by Maurer Faculty. 2081.

https://www.repository.law.indiana.edu/facpub/2081

This Article is brought to you for free and open access by the Faculty Scholarship at Digital Repository @ Maurer Law. It has been accepted for inclusion in Articles by Maurer Faculty by an authorized administrator of Digital Repository @ Maurer Law. For more information, please contact rvaughan@indiana.edu. 


\title{
THE DIFFERENTIAL SENTENCING OF WHITE-COLLAR OFFENDERS IN TEN FEDERAL DISTRICT COURTS*
}

\author{
JOHN HAGAN \\ University of Wisconsin-Madison \\ University of Toronto
}

\author{
Ilene H. NAgel (BeRNSTEIN) \\ Indiana University
}

\section{Celesta Albonetti \\ Indiana University}

American Sociological Review 1980, Vol. 45 (October):802-820

\begin{abstract}
While sociologists have long debated the relationship between the status characteristics of criminal offenders and the sentences they receive, they have done so with data sets drawn from state courts whose prosecutorial resources are focused almost entirely on low status defendants. Qualitative and quantitative data analyzed in this paper are drawn from ten federal district courts whose statutes and resources provide greater potential for the prosecution of the white-collar crimes of higher status offenders. Three questions are addressed: (1) Are there substantial jurisdictional differences in the prosecution of white-collar cases? if so, (2) Are there corresponding jurisdictional differences in the sentencing of white-collar cases? and (3) Within jurisdictions, are there further differences in the factors that influence sentencing decisions in white-collar as compared to other kinds of cases? The data are analyzed from a perspective that emphasizes organizational considerations: we conceptualize the criminal justice process as a loosely coupled system and the use of prosecutorial resources as proactive and reactive. We argue that the expanded prosecution of white-collar persons for their white-collar crimes requires a proactive prosecutorial policy and a tightening of the coupling between plea negotiations and sentencing decisions in the prosecutorial and judicial subsystems. Our quantitative analysis reveals that one district follows a uniquely proactive pattern. As expected, this proactive district also exhibits a unique leniency in the sentencing of college educated white-collar criminals that is related to earlier plea and charging decisions. A rather different and unanticipated pattern of leniency is found in this district for less educated white-collar offenders. A conclusion of this study is that there may be an inverse relationship between the volume of white-collar prosecutions and the severity with which they are sentenced.
\end{abstract}

The existence of systematic links between the status characteristics of criminal offenders and the sentences they receive has been debated for some time (see Hagan, 1974). This debate is grounded in issues of theory and policy. For example, Chiricos and Waldo (1975) regard a relationship between class position and sentencing as crucial to one prominent version (Chambliss and Seidman, 1971) of a conflict theory of crime, while the absence of such a relationship is usually deemed essential to notions of "equality before the law." It therefore is not surprising that this type of debate has generated a large volume of research (see Net-

\footnotetext{
* Direct all correspondence to: John Hagan; Department of Sociology; Erindale College; University of Toronto; Mississauga, Ontario L5L-1C6.

Research reported in this paper was funded by the Crime and Delinquency section of the National Institute of Mental Health. The authors wish to thank the anonymous reviewers of this manuscript for their helpful comments.
}

tler, 1979:40-6). What is surprising is the inconclusiveness of the findings that flow from this work.

The problem is not simply that these findings are inconsistent, although they are that. For all the studies that find little (e.g., Bernstein et al., 1977) or no (e.g., Chiricos and Waldo, 1975) relationship between status characteristics and sentencing, there are still those that find this relationship to be substantial (e.g., Swigert and Farrell, 1977; Lizotte, 1978). However, the larger issue is that the data sets on which these studies are based are widely thought to be inadequate. Specifically, critics (e.g., Greenberg, 1977; Hopkins, 1977; Reasons, 1977) note that the samples considered in these studies consist almost entirely of low status defendants, making this research mainly a matter of within- rather than between-class comparisons. Thus, while (to date) research of this type has focused on the sentencing of "traditional" or "common" 
crimes (e.g., murder, robbery, larceny, etc.), Hopkins (1977:177) points out that "The illegal activities of the middle and upper classes are typically such things as income tax evasion and, in the case of businessmen, price fixing, violation of pollution laws and misrepresentation in advertising."

Three problems account for the failure of recent research to consider the latter kinds of crimes, which usually are designated vaguely as "white-collar crimes." First, there is an uncertainty about what, and who, to study. The difficulty is that not all white-collar crimes (e.g., income tax violations) are committed by whitecollar persons, and not all white-collar persons commit white-collar crimes (e.g., the crimes of Patty Hearst). We respond to this problem in this paper by crossclassifying indicators of the status of the offender and the offense. This allows us to compare the prosecution and sentencing of the white-collar crimes of white-collar persons with the prosecution and sentencing of other offender-offense combinations (see later pages, herein, for further elaboration of this point). Second, the former kinds of white-collar crimes are prosecuted with their greatest frequency in the American federal courts. To date, most sociological research on sentencing has been done in the state courts. Third, much of the white-collar crime of whitecollar persons is "beyond incrimination" (Kennedy, 1970). That is, much of this white-collar "indiscretion" is handled in the civil courts, or not dealt with at all. However, this situation shows signs of change.

Some U.S. Attorney offices recently have begun to take increased initiative in the prosecution of white-collar persons and their white-collar crimes. The quantitative data analyzed in this paper consist of cases prosecuted and sentenced over a several-year period in ten federal district courts, including one of the first U.S. Attorney offices in this country reputed to have made the prosecution of white-collar cases a high priority; qualitative data, as well, were gathered through observations and interviews in these courts. The latter data are used first to ground the following discussion of "white-collar justice."

\section{THE SOCIAL ORGANIZATION OF WHITE-COLLAR JUSTICE}

To understand the sanctioning of white-collar persons and their white-collar crimes we must consider the system in which this occurs. In this section, we develop a perspective for viewing the operations of this system. The perspective we offer is derived from the work of others and from the interviews and observations gathered in site visits to the ten district courts. The districts and their principal cities are Eastern and Southern New York (Brooklyn and Manhattan), Northern Illinois (Chicago), Eastern Pennsylvania (Philadelphia), Maryland (Baltimore), Northern Texas (Dallas), Western Missouri (Kansas City), Northern Georgia (Atlanta), Central California (Los Angeles), and Eastern Michigan (Detroit). During the site visits we observed approximately 200 hours of court proceedings and conducted approximately 600 hours of interviews with the following court personnel: 9 Chief Judges and 42 Presiding Judges, 8 United States Attorneys and 48 Assistant United States Attorneys, 14 Probation Officers, 15 Administrators of Pre-Trial Services Agencies, 31 Magistrates, and 10 Chiefs of Public Defender Offices. ${ }^{1}$

Reiss (1971; 1974) conceptualizes the criminal justice system as a loosely articulated operating network of inputoutput relationships among a series of subsystems; a set of relationships that we

1 These interviews were conducted over a tenweek period, with one week spent in each of the ten districts. The ten jurisdictions comprise a purposive sample selected by the Supreme Court (under provisions of the Speedy Trial Act; see fn. 4) and intended to maximize the representation of major metropolitan and geographic areas across the United States. The first two authors of this paper conducted the interviews together, using a set of structured, open-ended interview schedules that are available on request. Our purpose was to interview a crosssection of court personnel across the ten districts. Unedited excerpts from these interviews are quoted in this article. One Chief Judge refused to be interviewed and two U.S. Attorneys were not available for interviews. However, the First Assistant to each of the latter U.S. Attorneys was interviewed and our coverage otherwise was quite comprehensive. These qualitative data were generated to correspond to the quantitative data discussed later in this paper. 
will refer to as a "loosely coupled system" (Hagan et al., 1979; see also Meyer and Rowan, 1977). Discretion is dispersed throughout this system, and mechanisms for systematizing this discretion appear to be the exception as much as the rule. Thus, Gibbs (1978:105) observes that “. . . the system actually appears to be an ungoverned mishmash," and Eisenstein and Jacob (1977:37) note that even "the judge does not rule or govern; at most, he manages, and often he is managed by others."' Reiss (1971:120) goes on to suggest that "the major means of control among the subsystems is internal to each" with the significant consequence that "each subsystem creates its own system of justice." This situation becomes problematic when the attempt is made in such a system to establish or shift policies and priorities. Indeed, one of the fascinating features of loosely coupled systems is their ability to circumvent such changes (see Meyer and Rowan, 1977).

Yet important changes in policies and priorities sometimes do occur, with systemwide repercussions. Within the criminal justice system, such changes are often implemented through the prosecutorial subsystem. Reiss (1974:690) indicates why and how:

By legal authority and by practice, prosecutors have the greatest discretion in the formally organized criminal justice network. ... The way that prosecutors exercise discretion over input and output varies considerably among jurisdictions. This variation is due partly to the organized forms of discretion available to a prosecutor in a given jurisdiction and partly to historical practice within that office. The discretionary decisions of prosecutors whether or not to file information can exercise substantial control over input into the system, while the quantity and quality of output are determined mainly by their decisions to nol pros or to plea bargain.

Drawing from Reiss (1971), Black (1973) and our own interviews, we suggest that this prosecutorial power can be exercised in two principal ways.

On the one hand, prosecutors can follow a reactive policy of law enforcement. Following this strategy, prosecutors can respond to police initiatives in the same way in which the police do to citizen com- plaints. That is, prosecutors can simply respond to what the police bring to their attention. Indeed, the influx of cases, the absence of ready avenues of diversion, and the scarcity of resources is such that most state courts can do little but react, and slowly at that. These are "courts of last resort." Many federal prosecutors also are reactive. Their assumption is often that court resources are most efficiently organized to satisfy the demands of enforcement agencies. This assumption is reflected in the explanation given us by a U.S. Attorney for his reluctance to pursue one type of white-collar crime.

It would be nice to investigate, let's say, public corruption. "Okay, FBI, I want you to go out and develop snitches in all the HEW places where they might be taking bribes" . . . but God knows how much time [that would take] and we don't have the resources to do that. If I had some prosecutors or some agents to whom I could say, "Okay, I don't mind you wasting a year investigating this because we want it looked into," then I could see doing that. But if you don't have the resources to do it, I just don't feel you are using your resources right.

This reactive view is summarized in a quote from another U.S. Attorney interview: "In my opinion, any time you deny an agency the right to enforce its federal laws, you are not doing the job you are put here for."

Other federal prosecutors find, in their roles, sources of flexibility that allow the development of proactive policies. First, federal prosecutors have jurisdiction over a broad range of white-collar offenses. Second, federal prosecutors can decline cases or defer them to state courts, reserving resources for cases they assign higher priority. Third, the ratio of personnel to cases is usually more favorable in federal than in state courts. Fourth, federal prosecutors often have investigatory resources-particularly, federal agencies like the Federal Bureau of Investigation, the Postal Service and the Internal Revenue Service-that the state courts do not. Consequently, U.S. Attorney offices in several large jurisdictions allocate their resources to proactively initiate and encourage the investigation and prosecution of high priority cases. Thus, one U.S. 
Attorney interviewed noted that "In terms of the decision-making process of how and what cases will be handled and what will be done, a lot [of decisions] are being made here and not in the agency." One way this is done is as follows.

The U.S. Attorney's office can investigate cases in the grand jury, where it generates information. In other words, we can initiate an investigation. What we do often is we initiate investigations and then bring in the agency that will have jurisdiction in that area and be working with that agency in terms of developing the grand jury investigation; but we are not limited to only acting on cases that come into the office after an agency has done an investigation. We ourselves can initiate the investigation, through the grand jury.

This proactive attitude is summarized in the observation of another U.S. Attorney that: "We don't sit back and wait for cases to walk in the door. We go out and make them."

However, use of grand juries is not sufficient to build important white-collar cases in a proactive fashion. Information and evidence are needed to begin building these cases. While in other prosecutions such information frequently comes from victims and witnesses, the white-collar crimes of white-collar persons usually are different: the complexity and diffuseness of the victimizations reduce the visibility of these crimes and, therefore, the likelihood of obtaining evidence from nonimplicated persons. ${ }^{2}$ A U.S. Attorney explains the problem this way:

... in these sort of activities, the only people with the information that you are going to have to convict are the participants. It is not like a bank robbery where innocent people watch and see and identify. The only way you can get these kinds of criminals is through information supplied by participants. You have to peel off the layers ... . and that is difficult. That is a burden that is tougher than the burden prosecutors in the past had to deal with.

\footnotetext{
${ }^{2}$ Beyond this, even when such evidence might be obtained through record searches, accounting procedures, and the analysis of documents, the amounts of material and the methods of investigation are so costly in man-hours and resources, both to develop and to present in court, that such efforts rarely are undertaken.
}

The questions that follow are What is the exact nature of this burden? and Why is this burden so difficult to bear? Our interviews suggest that the nature of the burden is negotiation: the development of cooperative witnesses through plea negotiation. The process and problems involved are suggested in another segment of the above interview.

The negotiation proceeds within the confines of reality. That is the advantage I think good defense counsel has. . . . He knows and can tell his client what is likely to happen, and how likely it is to happen. If we've got a weak case, we've got a weak hand. If you've got a really strong case, you hold four aces on the top and he doesn't have any choice. Well, he does have a choice. Some people just go down. They take their lumps and they don't want to talk. . . . One of the last chips we have is that we can say not only are we going to convict you and send you to prison and you aren't going to get anything. After that is all done, then we will put you in the grand jury and we will get the information anyway and you won't get any credit for it. Indeed at sentencing we will stand up and make a point of the fact that you refused to cooperate and that will be held against you and you will get even more time.

The proactive prosecution of whitecollar persons and their white-collar crimes, therefore, comes down to the problem of how to get the leverage required to "turn witnesses," and the key to obtaining this leverage is to forge a connection between plea negotiations and concessions and coercion in sentencing. In other words, prosecutors must overcome the tendency toward loose coupling between most parts of the criminal justice system, establishing instead a direct connection between plea negotiations and sentencing decisions in white-collar cases. This can be accomplished in at least two ways: by carefully managing the severity of the charges in these cases, so that judges can use statutory guidelines in arriving at lenient sentences, and by getting judges to reward negotiated pleas directly. That such sentencing decisions are generated is suggested by the following observation of an Assistant U.S. Attorney in charge of a subsection responsible for the prosecution of official corruption in the district best known in our sample for its 
early emphasis on white-collar crime: "I would say most judges understand that in order to expose official corruption you do have to give some concessions to people who are involved. Again, because only those people who are involved know and can testify about it."3 Depending on how

${ }^{3}$ The federal law itself can be an effective means toward this end. For example, the Mail Fraud Statute and the Travel Act have been used with considerable "legal craftsmanship"' to successfully prosecute important white-collar cases (see Henderson, 1977). An indication of the flexible way in which these statutes have been used to generate cooperation and achieve convictions is suggested by the following rather sardonic excerpt from a dissenting appeal court opinion. This appeal resulted from the successful prosecution (during the period of our study in what we later identify as a very proactive district) of a major bribery case.

I conclude by depicting a scenario which I have little doubt approximates the facts of this prosecution. Federal officials, getting wind of a deal between ... state legislators and the ... . industry, assign agents to investigate. In due course, immunity is promised to some of the involved legislators and company officials in return for their cooperation and testimony. Recording devices are placed on some of the immunized persons to obtain inculpating admissions from those who are the targets of the prosecution. Once the investigation is completed, consideration is then given to what federal offense, if any, has been committed. The Mail Fraud Statute? The Federal Travel Act? The investigation files are searched to find some mailings or evidence of interstate travel. The United States Attorney's office sifts through the mailings in the file and then constructs a legal theory in order that they may be used to form the basis for a charge of mail fraud. One fortuitous trip, totally incidental and unforeseen, by an unindicted coschemer forms the basis of the two travel-act counts. A conspiracy count is, of course, added. In this fashion, the Mail Fraud Statute and the Travel Act are subverted to purposes for which they were never intended. No longer are the mailings and travel considered essential or an integral part of the scheme; they are seen and used to obtain federal jurisdiction.

In the above case, the central "unindicted coschemer" was separately charged with one count of making a false statement on his Income Tax return (that is, the bribe), to which he pleaded guilty. The statutory maximum sentence for the latter offense was three years imprisonment, and this offender received one year on probation. The other legislators in this case were charged with mail fraud, conspiracy, and travel-act violations, exposing them to potential concurrent sentencing and a statutory maximum sentence of five years imprisonment on one count of mail fraud alone. All pleaded not guilty; one was acquitted, while the others received threeyear prison sentences and fines. A remaining group of corporate executives was charged with the same extensive these understandings are, one implication of the connection we have drawn between negotiation and sentencing will be an overall tendency toward the lenient sentencing of white-collar persons convicted of white-collar crimes. In the remainder of this paper we use our quantitative data to examine evidence of this and related possibilities outlined in the perspective we have developed.

\section{THE PROSECUTION AND \\ SENTENCING OF WHITE-COLLAR \\ CRIME IN TEN FEDERAL DISTRICT COURTS}

The quantitative data we will consider consist of 9,068 cases prosecuted, and 6,562 cases sentenced, in our ten district courts over a period beginning in 1974 and ending in 1977. These data were collected by the administrative office of United States Courts, and our use of the data is premised on an agreement not to identify individual districts in our analysis. ${ }^{4} \mathrm{Be}$ fore beginning this analysis, we must specify our operationalization of the concept of white-collar crime.

Although the term "white-collar crime" has gained currency in several languages and in popular thought, there is disagreement about its definition (see Geis and Meier, 1977). As indicated earlier, much of the problem involves the kinds of crimes and kinds of people involved. Our analysis is based on an operational definition that allows consideration of both the offender and the offense. We began with a listing of all offenses in the United States

offenses, pleaded guilty, and received one to two years' probation and fines. This case usefully illustrates the important role which plea and charge negotiation can play in a proactive district in the prosecution and sentencing of important white-collar cases.

${ }^{4}$ These data were collected with special provisions for quality control and comprehensiveness made possible through a mandate of the Speedy Trial Act of 1974 to evaluate the experimental bail reform program established under this Act. All but 88 cases (which came into the data set in 1974) are from the years 1975 through 1977. The provisions of the evaluation were that a population of cases was to be collected during this period. Our interviews in all ten districts indicated full cooperation in the fulfillment of this mandate. 
Code that could plausibly be thought of as white-collar crimes. ${ }^{5}$ We then refined this classification by asking U.S. Attorneys in the ten districts to approve or disapprove of the inclusion of offenses, asking each to identify offense codes that were almost always white-collar, sometimes whitecollar, and almost never white-collar. Thirty-one offenses that elicited considerable consensus as white-collar crimes were retained, ${ }^{6}$ and, for the purposes of

5 The original listing was made available to the authors by Stanton Wheeler and John Cardascia and consists of 53 offenses abstracted from the Code.

${ }^{6}$ A short description follows of 27 of these offenses, with the Title number, Section number, and number of cases involving a college educated offender indicated in parentheses: trust, etc., in restraint of trade (15:1:51); bankruptcy-concealment of assets, false oaths and claims, bribery (18:152:1); bribery, graft, and conflicts of interest-bribery of public officials and witnesses (18:201:5); bribery, graft, and conflict of interest-salary of government officials and employees payable only by U.S. (18:209:1); bribery, graft, and conflict of interestoffer to procure appointed public office (18:210:1); claims and services in matters that affect government-conspiracy to defraud the government in respect to claims (18:286:1); claims and services in matters that affect the government-false or fraudulent claims (18:287:12); embezzlement and theftaccounting for public money (18:643:1); embezzlement and theft-custodians generally misusing public funds (18:648:1); embezzlement and theft-theft, embezzlement or misapplication by bank officers or employees (18:656:57); embezzlement and theftlending, credit, and insurance institutions (18:657:6); embezzlement and theft-property mortgaged or pledged to farm credit agencies (18:658:1); embezzlement and theft-theft or embezzlement from employee benefit plan (18:664:1); fraud and false statements-statements or entries generally (18:1001:23); fraud and false statements-bank entries, reports, or false transactions (18:1005:2); fraud and false statements-federal crime institutions entries, reports, and transactions (18:1006:1); fraud and false statements-Department of Housing and Urban Development and Federal Housing Administration transactions (18:1010:2); fraud and false statements-Department of Housing and Urban Development transactions (18:1012:1); fraud and false statements-loan and credit applications generally, also renewals and discounts, crop insurance (18:1014:14); mail fraud-frauds and swindles (18:1341:56); mail fraud-fictitious name or address (18:1342:2); mail fraud-fraud by wire, radio, or telephone (18:1343:6); attempt to evade or defeat tax (26:7201:11); failing to file tax return (26:7203:28); fraud and false statements (26:7206:23); fiduciary responsibility of officers of labor organizations (29:501:1); fraudulent acceptance of paymentsveteran's benefit $(38: 3502: 6)$. Four additional offenses $(18: 2073 ; 26: 7207 ; 26: 7262 ; 49: 322)$ were des- this research, the other offenses were designated as common crimes. We proceeded by cross-classifying the dichotomy with two dichotomized measures of the offender's social standing: education (high school or less, and college or more) and income (less than $\$ 13,777$, and $\$ 13,777$ or more, per year, in 1974-1977 dollars). These are the most direct measures of social standing available in our data, and we have dichotomized them on the basis of Featherman and Hauser's (1978) recent replication of the work of Blau and Duncan (1967). Thus, our cut points correspond to the highest grouping of occupations considered in these studies. Analyses reported in this paper have been done separately for the education and income measures, with, as we will see partially in Table 1 , substantially similar results. However, in deference to space limitations, we present only the results involving education beyond Table 1. Education was selected over income for two reasons: it allows us to consider women without reported incomes in a more meaningful manner, and it avoids the problem of correcting for a deflating dollar over the several-year period. The resulting cross-classification that forms a central part of our analysis includes the following four kinds of cases: the common crimes of the less educated; the common crimes of the college educated; the white-collar crimes of the less educated; and the white-collar crimes of the college educated. As indicated earlier, the latter type of case is of greatest interest to us because it is the "purest" form of whitecollar crime we can identify and because we expect prosecution of this type of case to exhibit the most interesting variation across districts.

The first step in our analysis was to examine the distribution of prosecutions and dispositions for the four offenderoffense combinations in all ten districts. What we found was a striking similarity in these distributions for nine of the ten districts. The tenth, which we call District C,

ignated as white-collar by U.S. Attorneys in our interviews. However, these offenses did not result in convictions for college educated offenders in our data. 
Table 1. Prosecutions and Dispositions for Offender-Offense Combinations in District C and Other Districts*

\begin{tabular}{|c|c|c|c|c|c|c|}
\hline \multicolumn{4}{|c|}{ District $\mathrm{C}$} & \multicolumn{3}{|c|}{ Other Districts } \\
\hline \multicolumn{7}{|c|}{ Prosecutions } \\
\hline \multicolumn{4}{|c|}{ Education } & \multicolumn{3}{|c|}{ Education } \\
\hline Crime & High School & College & & High School & College & \\
\hline Common & $83.9 \%$ & $16.1 \%$ & & $83.3 \%$ & $16.7 \%$ & \\
\hline \multirow[t]{2}{*}{ Crime } & $86.3 \%$ & $56.7 \%$ & $79.6 \%$ & $91.6 \%$ & $80.5 \%$ & $89.5 \%$ \\
\hline & $\begin{array}{c}66.7 \% \\
(598)\end{array}$ & $\begin{array}{c}12.8 \% \\
(115)\end{array}$ & (713) & $\begin{array}{l}74.6 \% \\
(6094)\end{array}$ & $\begin{array}{l}15.0 \% \\
(1222)\end{array}$ & (7316) \\
\hline White- & $51.9 \%$ & $48.1 \%$ & & $64.4 \%$ & $34.6 \%$ & \\
\hline Collar & $13.7 \%$ & $43.3 \%$ & $20.4 \%$ & $8.4 \%$ & $19.5 \%$ & 10.4 \\
\hline Crime & $\begin{array}{c}10.6 \% \\
(95)\end{array}$ & $\begin{array}{c}9.8 \% \\
(88)\end{array}$ & (183) & $\begin{array}{l}6.5 \% \\
(560)\end{array}$ & $\begin{array}{l}3.6 \% \\
(296)\end{array}$ & (856) \\
\hline \multicolumn{7}{|c|}{ Convictions } \\
\hline \multicolumn{4}{|c|}{ Education } & \multicolumn{3}{|c|}{ Education } \\
\hline Crime & High School & College & & High School & College & \\
\hline $\begin{array}{l}\text { Common } \\
\text { Crime }\end{array}$ & $\begin{array}{c}83.7 \% \\
84.1 \% \\
63.8 \% \\
(443) \\
\bar{X} \text { sentence }=8.0\end{array}$ & $\begin{array}{c}16.3 \% \\
51.5 \% \\
12.4 \% \\
(86) \\
\text { ntence }=\end{array}$ & $\begin{array}{l}76.2 \% \\
(529)\end{array}$ & $\begin{array}{c}83.9 \% \\
90.7 \% \\
74.2 \% \\
(4352) \\
\bar{X} \text { sentence }=7 .\end{array}$ & $\begin{array}{c}16.1 \% \\
78.2 \% \\
14.3 \% \\
(838) \\
\text { ntence }=\end{array}$ & $\begin{array}{l}88.4 \% \\
(5190)\end{array}$ \\
\hline $\begin{array}{l}\text { White } \\
\text { Collar } \\
\text { Crime }\end{array}$ & $\begin{array}{c}50.9 \% \\
15.9 \% \\
12.1 \% \\
(84)\end{array}$ & $\begin{array}{c}49.1 \% \\
48.5 \% \\
11.7 \% \\
(81)\end{array}$ & $\begin{array}{l}23.8 \% \\
(165)\end{array}$ & $\begin{array}{r}65.6 \% \\
9.3 \% \\
7.6 \% \\
(445)\end{array}$ & $\begin{array}{c}34.4 \% \\
21.8 \% \\
4.0 \% \\
(233)\end{array}$ & $\begin{array}{r}11.6 \% \\
(678)\end{array}$ \\
\hline & $\bar{X}$ sentence $=4.1$ & ntence $=$ & & $\overline{\mathrm{X}}$ sentence $=4$ & ntence $=$ & \\
\hline \multicolumn{7}{|c|}{ Convictions } \\
\hline \multicolumn{4}{|c|}{ Income (1974-1977 \$) } & \multicolumn{3}{|c|}{ Income $(1974-1977 \$)$} \\
\hline Crime & $13,776-$ & $13,777+$ & & $13,776-$ & $13,777+$ & \\
\hline $\begin{array}{l}\text { Common } \\
\text { Crime }\end{array}$ & $\begin{array}{c}89.8 \% \\
85.4 \% \\
68.4 \% \\
(475) \\
\bar{X} \text { sentence }=7.6\end{array}$ & $\begin{array}{c}10.2 \% \\
39.1 \% \\
7.8 \% \\
(54) \\
\text { ntence }=\end{array}$ & $\begin{array}{l}76.2 \% \\
(529)\end{array}$ & $\begin{array}{c}92.9 \% \\
90.0 \% \\
82.1 \\
(4,819) \\
\bar{X} \text { sentence }=7\end{array}$ & $\begin{array}{c}7.1 \% \\
72.3 \% \\
6.3 \% \\
(371) \\
\text { ntence }=\end{array}$ & $\begin{array}{l}88.4 \% \\
(5,190)\end{array}$ \\
\hline $\begin{array}{l}\text { White } \\
\text { Collar } \\
\text { Crime }\end{array}$ & $\begin{array}{c}49.1 \% \\
14.6 \% \\
11.7 \% \\
(81) \\
\bar{X} \text { sentence }=4 .\end{array}$ & $\begin{array}{c}50.9 \% \\
60.9 \% \\
12.1 \% \\
(84) \\
\text { entence } 3 .\end{array}$ & $\begin{array}{l}23.8 \% \\
(165)\end{array}$ & $\begin{array}{c}79.1 \% \\
10.0 \% \\
9.1 \% \\
(536) \\
\bar{X} \text { sentence }=4 .\end{array}$ & $\begin{array}{r}20.9 \% \\
27.6 \% \\
2.4 \% \\
(142) \\
\text { ntence }=\end{array}$ & $\begin{array}{r}11.6 \% \\
(678)\end{array}$ \\
\hline
\end{tabular}

* Each cell of each cross-classification is percentaged first by row, second by column, and third in relation to the full cross-classification.

was distinguished by its disproportionate prosecution of white-collar persons involved in white-collar crimes. Table 1 presents the distribution of prosecutions and dispositions, by offender and offense, in District $C$ as compared to the other nine districts.

Table 1 reveals that while $9.8 \%$ of the prosecutions and $11.7 \%$ of the convictions in District $\mathrm{C}$ include college educated persons involved in white-collar crimes, the respective figures for the remaining districts are $3.6 \%$ (ranging from $2.7 \%$ to
$4.5 \%$ ) and $4 \%$ (ranging from $2.4 \%$ to $5.4 \%$ ). When income is used as the measure of social standing in Table 1, the disparity in convictions between District $C$ and the other districts increases slightly to $12.1 \%$ as compared with $2.4 \%$. At a minimum, then, District $\mathrm{C}$ prosecutes and convicts more than twice the proportionate number of white-collar persons for white-collar crimes as do the other districts. Thus, although the caseloads of none of the districts are overcrowded with the latter types of cases, both in prose- 
cutions and convictions, District $\mathrm{C}$ is clearly the deviant case. Yet another way of making this point is to indicate that, while District $\mathrm{C}$ prosecutes only $9.9 \%$ of the cases handled in all ten districts, it prosecutes $22.9 \%$ of the white-collar cases involving college educated persons. The respective conviction figures are $10.6 \%$ and $25.8 \%$, and $10.6 \%$ and $37.1 \%$ when income replaces education as the measure of social standing. These data suggest that whether education or income is used as the measure of social standing, District C has followed a uniquely proactive pattern in its prosecution of white-collar crime. ${ }^{7}$

Returning to Table 1, we should also note that in none of the districts does the prosecution of white-collar crime predominately involve what might conventionally be regarded as white-collar persons. Approximately half of the white-collar crimes prosecuted $(48.1 \%)$ and convicted $(49.1 \%)$ in District $\mathrm{C}$ involve college educated persons, compared to about one-third in the other districts (34.6\%; 34.4\%). A similar pattern prevails in the part of Table 1 that replaces education with income. Thus, although District $\mathrm{C}$ again demonstrates a more proactive emphasis on the white-collar crimes of white-collar persons, this emphasis is by no means exclusive. This finding is consistent with the observation of Katz $(1979: 433)$ that "There are relatively few crimes that can be committed only by those in white-collar occupations" and the observation of Geis (1974:284) that "white collar crimes can be committed by persons in all social classes." Federal prosecutors not only believe, but also act on, this assumption-pursuing, for example,

\footnotetext{
${ }^{7}$ District $\mathrm{C}$ is uniquely proactive in the sense that, by the measures applied, it is the most proactive district in our data. This said, we should also note that while the volume of white-collar cases prosecuted and convicted in District $C$ is not dramatic, the reallocation of resources required to pursue even this number of cases is probably substantial. Our point is simply that white-collar cases require a disproportionate investment of resources and that, therefore, the doubling of the proportionate number of prosecutions and convictions (albeit still not large) in District $\mathrm{C}$ is probably a more dramatic difference than it might otherwise seem. This point is addressed again, in a somewhat different way, in the conclusion to this article.
}

large numbers of bank clerks for smallscale embezzlements and less educated citizens for relatively small-scale income tax violations (see Long, 1979). The other side of this situation is that college educated persons, also, of course, are prosecuted and convicted for common crimes. In fact, there is rather striking consistency in the finding that approximately $16 \%$ of the prosecutions as well as of convictions for common crimes, in District $C$ as well as in other districts, involve college educated persons. Although the figures for income are smaller $(10.2 \%$ and $7.1 \%)$, there is consistency here as well. This consistency is in contrast to the variation we find in the prosecution and conviction of white-collar persons involved in white-collar crimes.

We have also included in Table 1 mean sentence scores (see Table 2 for the scale used) for the various offender-offense groupings. Several things are apparent in these figures.

First, although there is a general tendency across districts for white-collar crimes to result in lighter sentences than common crimes, the disparities involved are greater in District $C$ than in the other districts.

Second, in District $\mathrm{C}$, whether education or income is the measure of social standing, white-collar persons prosecuted for white-collar crimes receive the most lenient sentences. (By contrast, in the other districts, the lightest mean sentences are received by less educated and lower income persons prosecuted for white-collar crimes.)

Third, with the exception of instances when income is considered in District C, the common crimes of common criminals result in the most severe sentences.

Fourth, the largest disparity in mean sentences reported in Table 1 is within District $\mathrm{C}$, and it involves the common crimes of the less educated $(\bar{X}=8.04)$ and the white-collar crimes of the college educated $(\bar{X}=3.49)$.

Fifth, when comparisons are made between the same offender-offense groupings in District $\mathrm{C}$ and the remaining districts, the most consistent disparity observed across the districts is in the mean sentences received by college educated 
white-collar criminals $(\bar{X}=3.49$ and 4.64$)$ and high income white-collar criminals $\overline{\mathbf{X}}$ $=3.55$ and 4.98 ). A possible implication of these findings, consistent with the perspective outlined earlier in this paper, is that the proactive prosecution of whitecollar crime in District $C$ results in more lenient sentencing, particularly for whitecollar persons. However, before inferences are drawn from these findings, it is necessary to consider a number of other relevant variables. We do this in the multivariate analyses presented in following sections of this article.

Finally, although we might have expected more variation across districts in our data, we should note that the unique position of District $\mathrm{C}$ is not surprising. This is the District in our data set that is best known for its early emphasis on the prosecution of white-collar crime. This tradition was established most visibly by a U.S. Attorney who made the proactive pursuit of white-collar crime and political corruption a focal point of his work. The impression formed in our interviews, in the public statements of officials in the Department of Justice, and in recent highly publicized cases being pursued in the federal courts is that this is a style of administration that is going to become more prominent in the federal system. Thus, the following comparative analysis of sentencing patterns in District $\mathrm{C}$ and the other nine districts may be important to not only the debate on status characteristics and sentencing but to our understanding of the shape of things to come, as well.

\section{METHODS AND MEASUREMENT}

Table 2 presents the variables and their codings to be considered in this analysis. Variables are included on the basis of the perspective outlined above, prior research (e.g., Hagan, 1974; Chiricos and Waldo, 1975; Burke and Turk, 1975; Bernstein et al., 1977; Nagel, 1980; Swigert and Farrell, 1977), concerns for multicollinearity, and suggestions arising from our interviews. Thus, we began with a traditional list of variables that includes prior adult felony convictions, statutory seriousness of the offense, number of charges for which the defendant was convicted, ethnicity, sex, age, and employment status; then, we added to these consideration of whether or not the defendant was undergoing treatment for physical and/or mental illness. Our interviews suggested that the latter two variables might be particularly relevant for white-collar defendants. In addition, our sensitivity to the impact of prior processing decisions on sentencing suggested the inclusion of bail status (ordinally ranked on the basis of our interviews and on an evaluation of the fiscal and personal constraints involved), whether the defendant pleaded guilty, and a consideration of charge reductions. Since multiple defendants are common in white-collar cases, we also included a measure of their presence in our analysis. Several of the variables introduced thus far have particular significance for this study and are discussed further, here.

For example, statutory seriousness is an important variable to the perspective developed in this paper. This variable is measured in terms of the maximum prison sentence provided in the United States Code for the charge initially placed against the offender (charge reductions are considered below). Since white-collar crimes generally are assumed to carry lower statutory maximums then common crimes, ${ }^{8}$ and because prosecutors can also use their discretion in selecting the statutory seriousness of the charge, the statutory seriousness variable may be expected to form a particularly important link in the prosecution and sentencing of white-collar persons for white-collar crimes.

From the perspective on white-collar crime outlined earlier, the offender's plea is also expected to be a very significant link between prosecution and sentencing. At minimum, a guilty plea in such a case saves the resources otherwise required to establish guilt in court. Since important white-collar cases are characteristically complex, this is often a considerable savings. Beyond this, many guilty pleas in-

${ }^{8}$ Consistent with this assumption, there is a correlation of -.14 in our data between statutory seriousness and those white-collar crimes involving college educated persons. 
Table 2. Variables, Values, and Descriptive Statistics

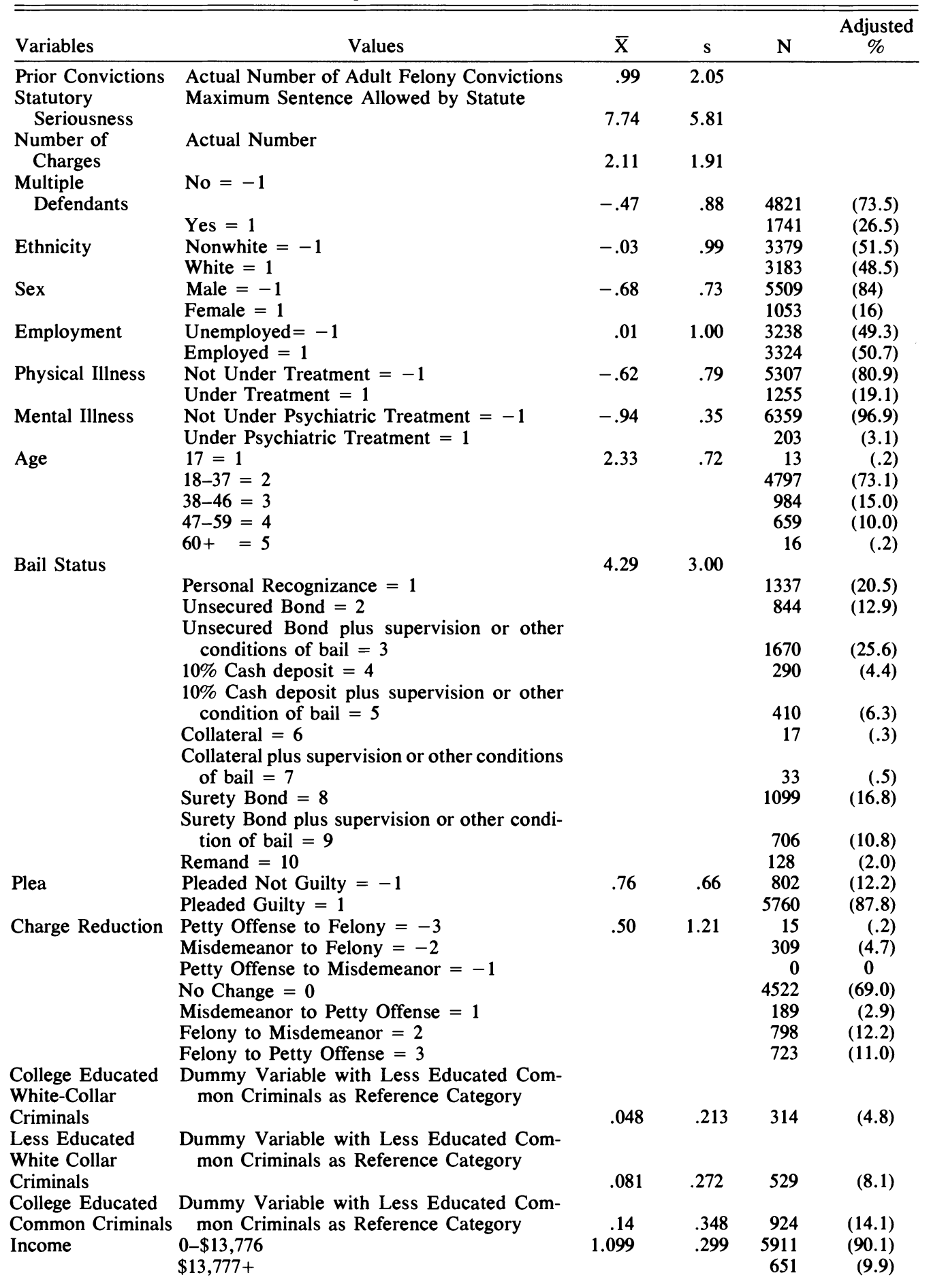


Table 2. Continued

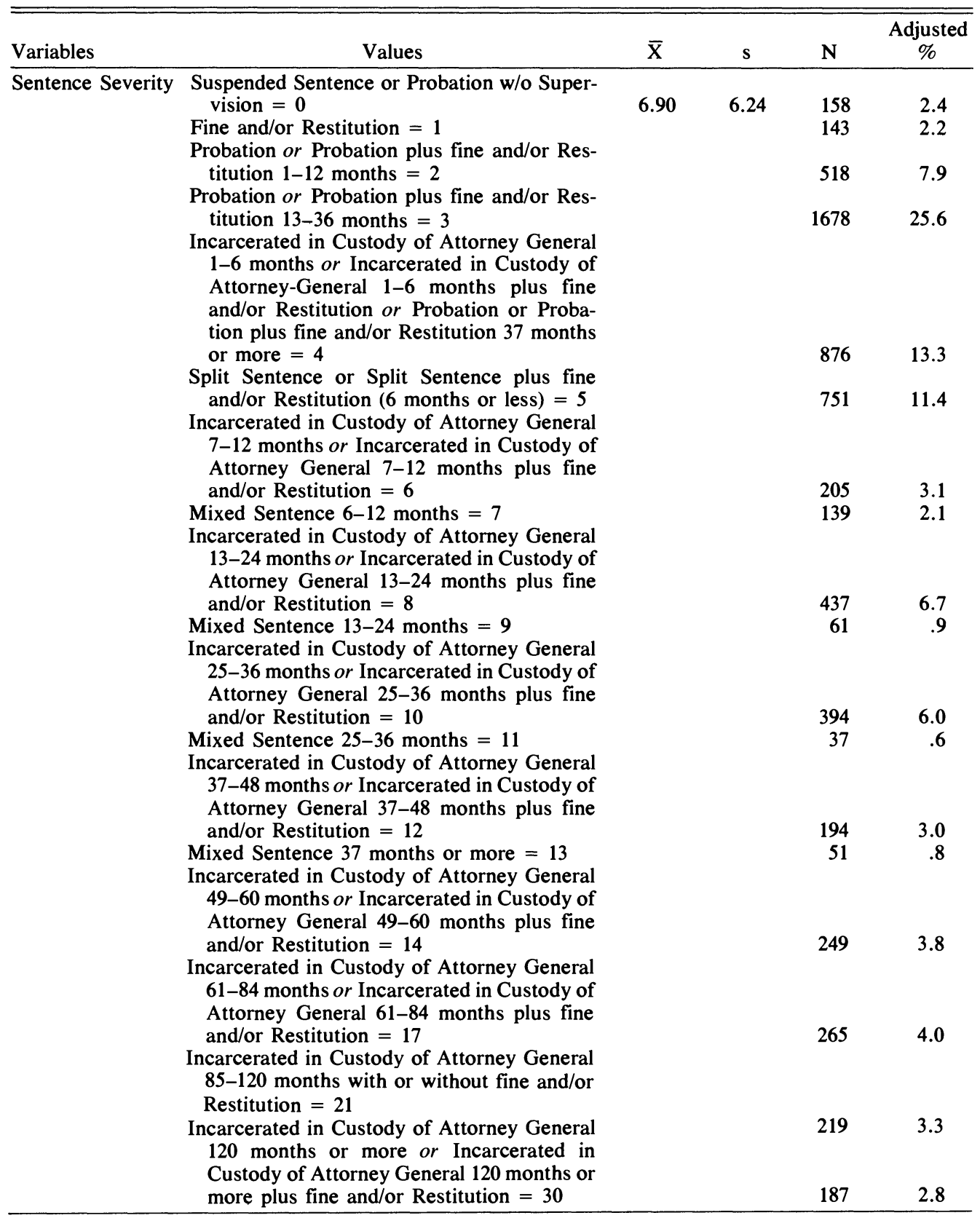

volve the cooperation of the offender in building a case against others. Thus, in these types of white-collar cases, we expect the plea entered to have a notable effect on the sentence imposedparticularly in a district where the prosecution of a large number of these cases is made a priority. This coupling between prosecutorial and judicial subsystems may be an important source of the differential sentencing of white-collar offenders. In this data set, guilty pleas are coded 1, pleas of innocence -1 .

Charge reductions may also influence sentence severity, as a way of rewarding cooperation in white-collar cases. Charge 
reductions are coded from -3 to 3 in terms of all six possible movements up and down in severity among petty offense, misdemeanor, and felony. No change is coded 0 . However, it should be noted that the possibilities for charge reductions in the federal courts are not as great as in the state courts:

The reason for this difference is that state criminal codes include lesser offenses to which charges frequently can be reduced, whereas the federal criminal code typically does not. . . . A result is more explicit recourse to discussions of sentencing and related sanctions. (Hagan and Bernstein. 1979:470)

The implication is that in the federal system the plea itself may be a more potent variable than the charge reduction.

The next three variables in Table 2 involve the offender and offense components of "white-collar crime. The three variables considered derive from a dummy coding (see Kerlinger and Pedhazur, 1973) of our earlier crossclassification of the offender's education and offense. Each of these variables, when included in the regression analyses that follow, yield a coefficient that represents the difference in sentence for cases classified as the specified offender-offense grouping compared to those that are classified as a designated "reference category." For the purposes of our analyses, we have designated the common crimes of less educated persons as our reference category. This will allow us to estimate an effect parameter for each of our offender-offense groupings, compared to the reference category, with all other variables in the regression equation taken into account. As an example, we will be able to examine whether the disparity-observed earlier in the sentences received by college educated white-collar criminals, as compared to less educated common criminals-persists when the other independent variables just discussed are taken into account.

The last variable in Table 2 , sentence severity, is our dependent variable. The coding of this variable derives from the efforts of Tiffany et al. (1975) to devise an approximate interval scale of the severity of different sentencing options. Minimal revisions in this scale derive from our interviews and are intended to reflect further gradations in the severity of sentences imposed.

Our analysis of the variables described above is based on conventional regression procedures. The strategy followed is to focus first on District $\mathrm{C}$, in comparison to all other districts. Our purpose is to examine comparatively the consequences of the proactive prosecution of white-collar crime in District C. The perspective developed earlier suggests that the proactive prosecution of white-collar persons for their white-collar crimes requires concessions in sentencing, and it is this possibility that we first consider. We then go on to examine more specifically the factors leading to severe or lenient sentencing for each of the four offender-offense combinations in District $C$, as compared to the other nine districts. This second phase of the analysis explores which of the other independent variables may contribute to the expected differential sentencing of white-collar offenders in District $\mathrm{C}$, as compared to the other districts. The perspective developed earlier suggests that concessions in the sentencing of these cases may follow from lenient initial charges, the rewarding of guilty pleas, and, possibly, charge reductions. These are the factors judged important in tightening the connection between the prosecutorial and judicial subsystems, thereby circumventing the obstacles posed to proactive prosecution in a loosely coupled system. Furthermore, if this tightening of connections between the prosecutorial and judicial subsystems does occur, we should also expect an increase in our ability to explain sentencing decisions in these types of cases-a consequence of a recognized common goal in a system otherwise characterized by divergent subsystem concerns. We also examine these expectations in the second phase of our analysis.

We should note that all comparisons undertaken in the remainder of this article effectively involve populations or subpopulations. That is, we are not dealing with samples, but, rather, with the full volume of cases involved in any given comparison (see footnote 4). Nonetheless, 
Table 4. Regression of Sentence Severity on Independent Variables for Offender-Offense Combinations in District C

\begin{tabular}{|c|c|c|c|c|c|c|c|c|c|c|c|c|}
\hline \multirow[b]{2}{*}{ Independent Variables } & \multicolumn{3}{|c|}{$\begin{array}{c}\text { Less Educated } \\
\text { Common Criminals } \\
(\mathrm{N}=443)\end{array}$} & \multicolumn{3}{|c|}{$\begin{array}{l}\text { Less Educated } \\
\text { White-Collar } \\
\text { Criminals } \\
(\mathrm{N}=84)\end{array}$} & \multicolumn{3}{|c|}{$\begin{array}{l}\text { College Educated } \\
\text { Common Criminals } \\
(\mathrm{N}=86) \\
\end{array}$} & \multicolumn{3}{|c|}{$\begin{array}{l}\text { College Educated } \\
\text { White-Collar } \\
\text { Criminals } \\
(\mathrm{N}=81) \\
\end{array}$} \\
\hline & b & B & s & b & B & $\mathbf{s}$ & b & B & $\mathbf{s}$ & b & B & $\mathbf{s}$ \\
\hline Prior Convictions & .55 & .15 & .00 & .21 & .20 & .086 & .1 & .07 & NS & -.07 & -.02 & $\overline{\mathrm{NS}}$ \\
\hline Statı & .01 & .01 & $\mathbf{N}$ & .07 & .09 & NS & .3 & .39 & .00 & .48 & .42 & .003 \\
\hline er of Cha & -.01 & -.01 & NS & .06 & .10 & NS & .2 & .17 & N: & -.05 & -.06 & NS \\
\hline Multiple Defendants & .43 & .07 & NS & -.24 & -.14 & NS & .14 & .03 & NS & -.41 & -.18 & NS \\
\hline Ethnicity & .50 & .08 & .07 & -.29 & -.18 & NS & -.37 & -.09 & NS & .14 & .04 & NS \\
\hline Sex & -.68 & -.06 & NS & -.03 & -.02 & NS & -.46 & -.07 & NS & -.42 & -.08 & NS \\
\hline lovment & -.78 & -.13 & .003 & -.48 & -.24 & .043 & .33 & .07 & NS & -.06 & -.02 & NS \\
\hline 1 Illness & .71 & .09 & .05 & -.01 & -.01 & NS & -.48 & -.08 & NS & .16 & .05 & NS \\
\hline Mental Illness & .22 & .01 & NS & .93 & .27 & .024 & 1.46 & .14 & $\mathbf{N}$ & .36 & .07 & NS \\
\hline Age & .19 & .02 & NS & .28 & .17 & NS & .15 & .03 & NS & -.01 & -.01 & NS \\
\hline Bail Status & .96 & .34 & .000 & .05 & .09 & NS & .53 & .24 & .07 & .15 & .13 & NS \\
\hline Plea & -.84 & -.10 & .016 & -.26 & -.07 & NS & -.88 & -.13 & NS & -1.26 & -.24 & .028 \\
\hline \multirow[t]{2}{*}{ Charge Reduction } & .72 & .13 & .002 & .11 & .08 & NS & -.42 & -.09 & NS & .48 & .16 & NS \\
\hline & \multicolumn{3}{|c|}{$\begin{array}{c}\mathrm{R}^{2}=.27 \\
\text { Intercept }=3.88\end{array}$} & \multicolumn{3}{|c|}{$\begin{array}{c}\mathbf{R}^{2}=.25 \\
\text { Intercept }=3.85\end{array}$} & \multicolumn{3}{|c|}{$\begin{array}{c}\mathrm{R}^{2}=.28 \\
\text { Intercept }=2.30\end{array}$} & \multicolumn{3}{|c|}{$\begin{array}{c}\mathbf{R}^{2}=.39 \\
\text { Intercept }=3.27\end{array}$} \\
\hline
\end{tabular}

white-collar criminals, while the remaining districts do not. However, this same pattern is apparent for less educated white-collar criminals. Thus, the issue that remains is whether these two offender-offense groupings actually differ in ways consistent with the perspective we have proposed. This issue is pursued in the next phase of our analysis.

Tables 4 and 5 present the results of regressing sentence severity on our independent variables within each of the four offender-offense groupings, first in District $\mathrm{C}$, then in the remaining districts. We note first in these tables that, consistent with the perspective outlined earlier, the highest explained variance involves the sentencing of college educated whitecollar offenders in District $C\left(R^{2}=.39\right)$. We take this as one indication of a tightening of connections in an otherwise loosely coupled system. Beyond this, however, we are anxious to determine where such a tightening in subsystem op-

Table 5. Regression of Sentence Severity on Independent Variables for Offender-Offense Combinations in Remaining Districts

\begin{tabular}{|c|c|c|c|c|c|c|c|c|c|c|c|c|}
\hline \multirow[b]{2}{*}{ Independent Variables } & \multicolumn{3}{|c|}{$\begin{array}{l}\text { Less Educated } \\
\text { Common Criminals } \\
(\mathrm{N}=4352)\end{array}$} & \multicolumn{3}{|c|}{$\begin{array}{l}\text { Less Educated } \\
\text { White-Collar } \\
\text { Criminals } \\
(\mathrm{N}=445)\end{array}$} & \multicolumn{3}{|c|}{$\begin{array}{l}\text { College Educated } \\
\text { Common Criminals } \\
(\mathbf{N}=\mathbf{8 3 8})\end{array}$} & \multicolumn{3}{|c|}{$\begin{array}{l}\text { College Educated } \\
\text { White-Collar } \\
\text { Criminals } \\
(\mathrm{N}=233)\end{array}$} \\
\hline & b & B & s & b & B & $\mathbf{s}$ & b & B & $\mathbf{s}$ & b & B & s \\
\hline Prior Convictions & .34 & .11 & .000 & .29 & .11 & .013 & .59 & .18 & .000 & .39 & .21 & .001 \\
\hline Statutory Seriousness & .24 & .22 & .000 & .04 & -.03 & NS & .29 & .23 & .000 & .04 & .02 & NS \\
\hline Number of Charges & .30 & .08 & .000 & .14 & .15 & .001 & .17 & .05 & .058 & .15 & .14 & .017 \\
\hline Multiple Defendants & .51 & .07 & .000 & .24 & .06 & NS & .42 & .06 & .027 & .26 & .07 & NS \\
\hline Ethnicity & -.47 & -.07 & .000 & .05 & .02 & NS & -.44 & -.07 & .010 & .03 & .01 & NS \\
\hline Sex & -.90 & -.10 & .000 & -.32 & -.12 & .011 & -.63 & -.07 & .017 & -.48 & -.13 & .047 \\
\hline Employment & -.54 & -.08 & .000 & -.06 & -.02 & NS & -.51 & -.09 & .003 & -.18 & -.05 & NS \\
\hline Physical Illness & -.11 & -.02 & NS & .05 & .02 & NS & .15 & .02 & NS & .11 & .03 & NS \\
\hline Mental Illness & -.38 & -.02 & NS & 2.01 & .23 & .000 & -.01 & -.01 & NS & .11 & .01 & NS \\
\hline Age & -.19 & -.02 & NS & .12 & .05 & NS & -.05 & -.01 & NS & .56 & .17 & .007 \\
\hline Bail Status & .83 & .38 & .000 & .30 & .25 & .000 & .75 & .39 & .000 & .40 & .32 & .000 \\
\hline Plea & -.81 & -.08 & .000 & .27 & .06 & NS & -.43 & -.05 & NS & .12 & .02 & NS \\
\hline \multirow[t]{2}{*}{ Charge Reduction } & .14 & .03 & .041 & -.07 & -.02 & NS & .10 & .02 & NS & -.27 & .07 & NS \\
\hline & \multicolumn{3}{|c|}{$\begin{array}{c}\mathrm{R}^{2}=.32 \\
\text { Intercept }=.537\end{array}$} & \multicolumn{3}{|c|}{$\begin{array}{c}\mathrm{R}^{2}=.21 \\
\text { Intercept }=4.80\end{array}$} & \multicolumn{3}{|c|}{$\begin{array}{c}\mathrm{R}^{2}=.35 \\
\text { Intercept }=.564\end{array}$} & \multicolumn{3}{|c|}{$\begin{array}{c}\mathrm{R}^{2}=.29 \\
\text { Intercept }=1.33\end{array}$} \\
\hline
\end{tabular}


erations may occur. Thus, our next interest is in comparing the effects of our independent variables on sentence severity, particularly in cases of college and less educated white-collar offenders. Comparison of the latter offender-offense groupings will help to determine whether the lenient sentencing observed above for both of these groupings in District $\mathrm{C}$ follows from similar or different types of considerations.

Within District $\mathrm{C}$, and in relation to the remaining districts, such comparisons reveal very different patterns of effects. For example, we find in Table 4 that, consistent with our perspective, in District C statutory seriousness (the seriousness of the initial charge) has the biggest effect on the severity of the sentences received by college educated white-collar defendants $(B=.42, p=.003)$. In contrast, the effects of this variable for the comparable cases in Table 5, and for the cases of less educated white-collar criminals in Table 4, are negligible $(\mathrm{B}=.02$ and .09 ).

To extend our understanding of this rather striking difference, we generated the frequency distributions of statutory seriousness in both District $\mathrm{C}$ and the remaining districts. These distributions are presented in Table 6 . What we find is that, although this variable has approximately the same standard deviation in District $\mathrm{C}(\mathrm{s}=5.90)$ and in the other districts $(s=5.79)$, the difference between these distributions is nonetheless dramatic. In District $C$, the modal initial charge carries a maximum sentence of one year in prison; in the remaining districts, the modal initial charge carries a

Table 6. Frequency Distributions of Statutory Seriousness in District $C$ and the Remaining Districts

\begin{tabular}{cccccc}
\hline & & & \multicolumn{2}{c}{$\begin{array}{c}\text { Remaining } \\
\text { Mistricts }\end{array}$} \\
\cline { 2 - 3 } No. of Years & No. & $\%$ & & No. & $\%$ \\
\cline { 2 - 3 } & 49 & 60.5 & & 31 & 13.3 \\
2 & 2 & 2.5 & & 15 & 6.4 \\
3 & 5 & 6.2 & & 25 & 10.7 \\
5 & 24 & 29.2 & & 156 & 67.0 \\
10 & 1 & 1.2 & & 2 & 1.0 \\
15 & 0 & 0.0 & & 4 & 1.7 \\
& $\bar{X}=6.74$ & & $\bar{X}=7.87$ \\
& $s=5.90$ & & $s=5.79$ \\
\hline
\end{tabular}

maximum sentence of five years. Beyond this, both distributions tend to be bimodal: each has a concentration of charges in the one- and five-year categories. The difference is that District $C$ has a bigger concentration of cases toward the nonserious end of the continuum, while the remaining districts have their heaviest concentration of cases more toward the serious end. The bimodal character of these distributions is consistent with our suggestion that, to successfully build the evidence necessary to get convictions in major white-collar cases, it is necessary to offer concessions in other potentially serious cases. What is most interesting from our perspective, however, is that this pattern is particularly pronounced in District $\mathrm{C}$, where whitecollar crime has been pursued in a very proactive fashion.

Also consistent with our perspective is the effect of the next most influential variable, the plea, in the sentencing of college educated white-collar criminals in District C. Those who plead guilty in District C (b $=-1.27, \mathrm{p}=.028)$ are more likely to get lenient sentences, while no similar significant effect $(b=.12)$ exists in the remaining districts, or for less educated white-collar criminals in District $\mathrm{C}(\mathrm{b}=-.26)$. From our perspective, the implication is that prosecutors in the proactive district are successful in getting judges to reward and punish the cooperativeness of college educated white-collar offenders. As expected, then, the two most important variables explaining the tendency in District $\mathrm{C}$ to sanction more leniently college educated white-collar criminals are their pleas and the initial charges placed against them. We will also discuss a quite different pattern that is apparent in cases of less educated white-collar offenders.

One other variable, charge reduction, is noteworthy for its absence of effect on the sentencing of white-collar cases in all districts. As indicated earlier in our discussion, this may be a result of the limited opportunities for charge reduction in the federal system. The effect of this situation may be to relegate much prosecutorial negotiation to less visible stages that precede initial charging decisions. We have already noted that, in District $\mathrm{C}$, the statutory seriousness of the initial charge has 
its most pronounced effect for college educated white-collar criminals. In contrast, in the more reactive remaining districts statutory seriousness has a prominent effect in the cases of less educated common criminals. The volume of these cases and the influence of this variable may reflect the tendency of these more reactive districts to balance the needs and wishes of the enforcement agencies that focus on more traditional crimes.

We turn now to a consideration of a very different pattern of effects apparent in the sentencing of less educated whitecollar criminals in both District $\mathrm{C}$ and the remaining districts. At this point it may be useful to recall that these cases consist in large part of income tax violations and bank clerk embezzlements. Since we did not anticipate the lenient treatment that these offenders receive in District $C$, our interpretation of these effects is, clearly, ad hoc. Nonetheless, we will begin by offering one suggestion as to why college and less educated white-collar crininals receive a similar type of leniency in District $C$. This suggestion is no more complicated than the observation that similar types of charges are placed against these offenders and that, once concessions are granted to the higher status white-collar offenders, it may be difficult not to grant them more generally, at least where similar statutory provisions are involved. In more familiar terms, a privilege once granted is difficult to deny later. Beyond this, it seems plausible to interpret the pattern of effects for this group in District $\mathrm{C}$ in terms of a compliance, as much as a punishment, model. Thus, the two most prominent findings for this group in District $\mathrm{C}$ are that being employed results in more lenient sentences $(B=-.24)$, while being under psychiatric treatment results in more severe sentences $(B=.27)$. The former finding applies only in District $\mathrm{C}$, while the latter finding applies in the remaining districts as well. This second counter-intuitive finding apparently results from a provision in the federal code which allows offenders thought mentally ill to be institutionalized for a 90-day "psychiatric study," and, then, to be resentenced at the end of this period. Alternatively, the finding in District $\mathrm{C}$ of greater leniency for those offenders who remain employed probably reflects a willingness to let these offenders work out arrangements to make restitution in lieu of more severe punishments. The concern, at least in District $\mathrm{C}$, would seem to be as much with remedying the behavior as with punishing it. In any case, we clearly have demonstrated that the differential leniency experienced by college and less educated white-collar offenders involves some very different considerations. We take this as support for our argument that the lenient sentencing of white-collar persons for their white-collar crimes derives from a set of circumstances that distinguish the proactive prosecution of this type of case.

A final finding, consistent across all districts, merits our attention. This finding is that bail status has a substantial impact on sentencing that is particularly consistent for common criminals (the B's range from .24 to .39). The implication of this finding is that negative bail decisions have particularly disadvantaging consequences for all kinds of common criminals. This finding is not new, but it is nonetheless interesting to find that it holds in the federal courts, bound by the Federal Bail Reform Act, as well as in the state courts (see Bernstein et al., 1977).

\section{CONCLUSIONS}

Gilbert Geis (1974) has made two important points about the study of whitecollar crime. The first point is that relatively few original pieces of research have been published on white-collar crime during the past two decades (see also Wheeler, 1976). The second point is that further study of white-collar crime is important because it can tell us a great deal about the way power is exercised in our society. To these important points, we would add another: examination of the prosecution and sentencing of white-collar crime can tell us much about how the social organization of a particular type of crime can influence the way it is controlled. In turn, this type of understanding may do much to enlighten a long tradition of research on status characteristics and sentencing.

We noted in the beginning of our dis- 
cussion that the above type of sentencing research has suffered from inadequate data. The inadequacy of these data is less the failing of social researchers than it is a failure of the system to prosecute and sentence any large volume of important white-collar cases. The infrequency of these prosecutions derives not only from the power of the persons involved but also from the manner in which these criminal activities are organized. Most common crime involves victims or witnesses and is pursued reactively in response to their complaints. In contrast, most white-collar crime involving white-collar persons is characterized by a diffuseness of victimization and an absence of unimplicated witnesses. As a result, a proactive organization of legal resources usually is required to seek out and build these white-collar cases. Since, frequently, only the participants in these criminal events can provide the information necessary to build successful cases, prosecutorial negotiation becomes a key part of the proactive prosecution of these cases. Furthermore, to make this negotiation work, a connection must be forged between the prosecutorial and judicial subsystems, such that the promises and concessions offered white-collar offenders are actually confirmed at sentencing. We have argued that this type of connection is the exception more than the rule in a criminal justice process we have called a loosely coupled system.

The overall implication of the organizational relationships we have described is, of course, that white-collar persons will receive lenient sentences for their whitecollar crimes. However, it is important to note that this disparity might be expected only where the prosecution of white-collar cases is proactive enough to generate a large volume of cases. This is, of course, exactly what we found in our data: college educated white-collar criminals received more-lenient sentences only in District C, our most proactive district.

What we did not anticipate on the basis of the perspective developed in this paper is that less educated white-collar criminals would also receive lenient sentences in District C. A question that follows from this finding is whether the white-collar crimes of more-highly educated persons are actually handled in the unique way our perspective suggests. However, our subsequent analysis of cases falling within the separate offender-offense groupings confirmed that quite different factors were involved in the sentencing of each, and that college educated white-collar persons indeed were sentenced on the basis of several of the considerations emphasized by our perspective. In an ad hoc fashion, we speculated that one reason less educated white-collar criminals may also receive lenient sentences in District $\mathrm{C}$ is because they are charged under similar statutes: once these statutes are used in a lenient fashion, it may be difficult to deny their wider application. This interpretation is consistent with our earlier findings that at a bivariate level it is college educated white-collar criminals who actually receive the most-lenient sentences in District $\mathrm{C}$, and that it is a higher concentration of this latter type of case in District C that makes it most unique. Nonetheless, we take these findings collectively as indicating the importance of further research on the ways in which types of persons, crimes, and control strategies interact.

More generally, our findings have theoretical-as well as policyimplications. They suggest, on the one hand, why previous research has rarely found relationships between status characteristics and sentencing to be large: as critics have suggested, there simply may not have been enough variation in the types of offenders and offenses studied to generate such relationships. This does not make the prior research wrong; it simply makes it representative of the types of courts studied. On the other hand, the modest relationship reported in this study, for District $\mathrm{C}(\mathrm{r}=.21 ; \mathrm{b}=-2.72 ; \mathrm{B}=-.16)$, may be all the more striking given thateven in this proactive district-college educated white-collar criminals make up only $11.7 \%$ of the population sentenced (cf. Cohen and Cohen, 1975:178). The interesting possibility this point raises is that the observed relationship may grow as the volume of cases (or, in other words, the level of proactive prosecution) increases. Put differently, there may be an inverse relationship between the volume 
of white-collar convictions and the severity of white-collar sentences. At this point, concerns about deterrence and equal treatment may come into conflict: convictions may be enough to deter some white-collar crime, but they are not enough to establish a sense of parity in the treatment of white-collar and common crime.

These concerns are aggravated by the further findings that the lenient sentencing of college educated white-collar criminals in our proactive district apparently is associated with the less-serious charges placed against these offenders and with a rewarding of their guilty pleas. The sense is of a style of prosecution that gives preferential treatment to highly educated white-collar offenders. That this may be what is required to successfully prosecute important white-collar cases is an uncomfortable paradox that policy makers as well as theorists will do well to consider.

We should also note other less central, but no less significant, findings of this research. Among the less educated whitecollar criminals in District $C$, we found that employment and mental illness were prominent factors in determining sentences: employment led to leniency, while treatment for mental illness resulted in severity. The latter finding was explained in terms of a federal provision that allows offenders thought mentally ill to be placed in penal institutions for psychiatric study; the former finding probably reflects a willingness to allow offenders in this grouping who are still employed to work out arrangements for making restitution. We suggested that in cases of less educated white-collar criminals the concern may be as much with obtaining compliance as with imposing punishment. Finally, quite apart from the preceding group of offenders, we also found that bail decisions have pronounced effects on the sentencing of common criminals. A theoretical implication of this finding is that bail outcomes may constitute one of the most salient kinds of legal labelling that common criminals experience.

The findings of this research do not encourage a reliance on law reform as an effective means of reducing sentence dis- parities. Notwithstanding important reforms in the federal bail system, we have found that bail decisions still exert a persistent impact on the severity of the sentences received by common criminals. Even more significantly, however, we suggest that the independence and variability of prosecutors demonstrated in this study is a neglected consideration which should reduce widespread expectations that recodification of the criminal law, sentencing guidelines, and reform or elimination of parole will eliminate sentencing disparities. Such reforms can readily be counteracted by shifts in prosecutorial policies on charging and plea bargaining and this seems particularly likely in an area as socially and legally sensitive as white-collar crime. The differential sentencing of white-collar offenders is a social as well as a legal problem.

\section{REFERENCES}

Bernstein, Ilene Nagel, William R. Kelly, and Patricia A. Doyle

1977 "Societal reaction to deviants: the case of criminal defendants." American Sociological Review 42:743-55.

Black, Donald

1973 "The mobilization of law." Journal of Legal Studies 2:125-49.

Blau, Peter, and Otis Dudley Duncan

1967 The American Occupational Structure. New York: Wiley.

Burke, Peter, and Austin Turk

1975 "Factors affecting postarrest dispositions: a model for analysis." Social Problems 22:313-32.

Chambliss, William J., and Robert B. Seidman

1971 Law, Order and Power. Reading, Mass.: Addison-Wesley.

Chiricos, Theodore G., and Gordon P. Waldo

1975 "Socioeconomic status and criminal sentencing: an empirical assessment of a conflict proposition." American Sociological Review 40:753-72.

Cohen, Jacob, and Patricia Cohen

1975 Applied Multiple Regression/Correlation Analysis for the Behavioral Sciences. New York: Wiley.

Eisenstein, James, and Herbert Jacob

1977 Felony Justice. Boston: Little, Brown.

Featherman, David, and Robert Hauser

1978 Opportunity and Change. New York: Academic Press.

Geis, Gilbert

1974 “Avocational crime." Pp. 273-98, in Daniel Glaser (ed.), Handbook of Criminology, Chicago: Rand McNally.

Geis, Gilbert, and Robert F. Meier

1977 White Collar Crime. New York: Free Press. 
Gibbs, Jack P.

1978 "Deterrence, penal policy, and the sociology of law." Pp. 101-14, in Rita Simon (ed.), Research in Law and Sociology. Greenwich, Connecticut: JAI Press.

Greenberg, David F.

1977 "Socioeconomic status and criminal sentences: is there an association?" American Sociological Review 42:174-6.

Hagan, John

1974 "Extra-legal attributes and criminal sentencing: an assessment of a sociological viewpoint." Law and Society Review 8:357-83.

Hagan, John, and Ilene Nagel Bernstein

1979 "The sentence bargaining of upperworld and underworld crime in ten federal district courts.' Law and Society Review 13:467-78.

Hagan, John, John Hewitt, and Duane Alwin

1979 "Ceremonial justice: crime and punishment in a loosely coupled system." Social Forces 58:506-27.

Hargens, Lowell

1976 "A note on standardized coefficients as structural parameters." Sociological Methods and Research 5:246-56.

Henderson, Thomas

1977 "The expanding role of federal prosecutors in combating state and local political corruption." Cumberland Law Review 8:385-401.

Hopkins, Andrew

1977 "Is there a class bias in criminal sanctioning?' American Sociological Review

Katz, Jack $42: 176-7$

1979 "Legality and equality: plea bargaining in the prosecution of white collar and common crimes." Law and Society Review 13:431-60.

Kennedy, Mark C.

1970 "Beyond incrimination." Catalyst 5:1-27.

Kerlinger, Fred, and Elazor Pedhazur

1973 Multiple Regression in Behavioral Re- search. New York: Holt, Rinehart, and Winston.

Lizotte, Alan J.

1978 “Extra-legal factors in Chicago's criminal courts: testing the conflict model of criminal justice." Social Problems 25:564-80.

Long, Susan

1979 "The Internal Revenue Service: examining the exercise of discretion in tax enforcement." Paper presented at the Annual Meeting of the Law and Society Association, San Francisco.

Meyer, J. W., and B. Rowan

1977 "Institutionalized organizations: formal structures as myth and ceremony." American Journal of Sociology 83:340-63.

Nagel, Ilene

1980 "The behavior of formal law: a study of bail decisions." Unpublished manuscript, In-

Nettler, Gwynn diana University, Bloomington.

1979 "Criminal justice." Annual Review of Sociology 5:27-52.

Reasons, Charles E.

1977 "On methodology, theory and ideology." American Sociological Review 42:177-80.

Reiss, Albert J., Jr.

1971 The Police and the Public. New Haven: Yale University Press.

1974 "Discretionary justice." Pp. 679-99, in Daniel Glaser (ed.), Handbook of Criminology. Chicago: Rand McNally.

Swigert, Victoria Lynn, and Ronald A. Farrell

1977 "Normal homicides and the law." American Sociological Review 42:16-32.

Tiffany, Lawrence P., Yakov Avichai, and Geoffrey W. Peters

1975 "A statistical analysis of sentencing in federal courts: defendants convicted after trial, 1967-1968.' Journal of Legal Studies 4:369-90.

Wheeler, Stanton

1976 "Trends and problems in the sociological study of crime." Social Problems 23:525-34. 